\title{
Significance of management in valorization of old urban units based on Montenegrin example
}

\author{
Rifat Alihodzic ${ }^{1, *}$ \\ ${ }^{1}$ University of Montenegro, Faculty of Architecture, Podgorica, Montenegro
}

\begin{abstract}
This paper, through study case of Montenegro, deals with significance of sophisticated management in process of activation of old urban units and some architectural facilities for tourist purposes. Starting fact is that one of the most important segments of tourist offer is immobile cultural heritage, having the value manifested in few segments, emphasizing two most famous. The first one represents urban agglomerations, successfully transposed into tourist offer, while the other segment is vencular residential architecture of indeginous type, which can also contribute to tourist offer with appealing its contents. This work also gives the example of target potentials. Examples mentioned in this work proved as successful and profitable (in economic way). Also, some of examples in the work are opportunities missed because of serious devastation of architectural and urban designing heritage, as well as real chances certain localities have. Specific case analysis proved that management is not present enough and not educated enough - it is far below disposable potentials Montenegro possesses. This work also points, through implemented researches, the degree of personnel, who are in charge for promoting values of traditional architecture for tourist purposes. However, logical conclusion can be drawn that the conscience about quality of old urban entities and vernacular heritage is not developed enough. That initiates requirement for educating managers and forming of multidisciplinar teams so the knowledge could be used for proper valorization of potentials. Significance of proper and qualified personnel is specially emphasized when this topic is studied, because investors are not educated enough on this issue, so disposable means are used for some other things marked and recognised as proper and profitable investments.
\end{abstract}

\section{Introduction}

Main prerequisite for using old urban units and vernacular architecture for touristic purposes is establishing of proper comitting management plans for Montenegro as a whole or for all its municipalities.

Management Plan is supposed to give a vision of economical and sustainable management of certain interesting urban units and facilities as well as their realisation for purposes of tourist valorization [1]. Management Plan should be expressed thorough general

\footnotetext{
*Corresponding author: rifata@ac.me
} 
aims and specific activity programes. That means defining of specific mechanismas and activiry carriers. Also, realisation deadlines should be defined by subject documentation.

Goal of Management Plan should consist of valorization, protection and promotion of disposable potentials. Hence, establishing of balance between preserving values and development on one side and using of area on principle of sustainable development on the other side, has a strategic significance. Management Plan gives vision of conducting protected areas for period of more than one year [2].

Such attitude considers work of multidisciplinary teams, which ought to perceive all possible potentials that may have benefit out of their realization.

Montenegro does not possess overall Management Plan of such kind. Only two municipalities prepared document like this - Kotor [3] and Cetinje [4].

\section{Potentials}

Considering this is a case study of specific example, it is essential to look back to disposable potentials of old agglomeration and vernacular architecture valorized and especially to those which could be used as to existing addition to existing tourist offer.

Montenegro, both in climate and functional space sense, consists of three regions: seaside, central and north [5].

1. Seaside region includes zone from Ulcinj (South) up to Herceg-Novi (South-West). Of course, important potential is Boka Kotorska Bay. This region includes important cities such as Ulcinj, Bar, Budva, Kotor and Herceg-Novi with their hinterland areas. One peculiarity of Boka Kotorska Bay is the municipality of Perast with its features.

Ulcinj's Old Town contains many temporal architectural layers, the last one originating from Ottoman period. As such, it offers significant potentials, only partially explored and used [4].

Bar, as well, offers Old Town as urban centre having long history and tradition, with the most remarkable parts originating from Ottoman period, but preserved in poor condition [5]. Beside its urban core, potentials of this municipalitiy can also be presented in vernacular architecture of hinterland villages in Gornja Brca and especially in Skadar Lake vicinity, where, as a specific example, beside Virpazar, village Godinje can be taken [6].

Budva has the most important potential in Old Town, situated on the very shore and it is a perfect example of tourist valorization. The same can be applied for Sveti Stefan.

Kotor and its Old Town retain UNESCO protection. Perast, a significant old unit, belongs to Kotor's territory. Considerable old urban units are: Risan, Dobrota, Orahovac, Skaljari, Muo, Prcanj, Kostajnica, Stoliv, Morinj and Lipci.

Herceg-Novi is situated on the very beginning of Boka Kotorska Bay. Description ,,cityfortress" perfectly suits. Beside its peculiar urban core, this city has significant marks of Venetian Republic, Ottoman Empire and Austro-Hungarian Monarchy on its urban matrix. Special rarity is island of Mamula with its significant potentials.

Peculiar cases, when considering these tourist potentials, are fortresses from AustroHungarian period [7].

2. Central region of Montenegro consists of cities: Podgorica, Cetinje, Danilovgrad and Niksic.

When talking about this region, Cetinje definetely has the largest tourist potentials. It is the old royal capital of Montenegro, which announced this status in 1878, when modern state of Montenegro was proclaimed. Beside its urban core, Rijeka Crnojevica, being a fishermen's village and small port, can be listed as tourist potential. Also, Njegusi is the significant tourist area for its tradition and vernacular architecture.

Potentials of Podgorica, for developing tourism based on old urban entities, can be found in Old Town, marvelous but not explored yet. 
3. North region consists of municipalities: Andrijevica, Berane, Bijelo Polje, Kolasin, Mojkovac, Pljevlja, Plav, Pluzine, Savnik, Rozaje, Zabljak.

Northern region of Montenegro is a composition of urban settlements, mostly dveloped under the reign of Ottoman Empire on these areas. The most peculiar features of them, even nowadays (in some traces), were residential areas and urban complexes. Special value in this period had Pljevlja, Plav, Gusinje and Rozaje. Slightly less important were Bijelo Polje and Berane. These urban cores are devastated today with ruthless devastation and they are gone because of temporal issues. Apparently, this architecture was mostly made out of woods.

However, particular examples of residential architecture from Ottoman period, are still existing in all these towns, and they can be valorized for tourist purposes.

Some remarkable examples of residential towers are still preserved in Plav and Gusinje, with Redzepagic Tower as the most famous one, whereas there is only one of such kind in Rozaje (Ganic Tower). They are made out of stone pedestal and the upper floor made out of wood. Another kind of residential tower is preserved in these areas - defensive tower, completely made out of quilted stone or carved stone [8].

Another remarkable example of varnecular architecture is the architecture of Dinaric type, originally preserved still, especially in area around Bijelo Polje. Dinaric type of house is a special kind, one of three types of residential facilities representing vernecular architecture of Montenegro [9].

\section{Examples of proper tourist valorization in Montenegro}

When the total image of valorized potentials of this kind is been looked upon, it is obvious that south part of Montenegro is far more advanced when such potentials are exploited. Summer tourism Adriatic coast development, influenced perception of certain potentials that are immediately recognized. Their active promotion and considerable contribution in tourist offer were fully proved after their activation. The most important capacities were shown, which management recognized and developed. Of course, spontaneous tourist development of individual initiatives was never factor less important.

1. Sveti Stefan, in Budva municipality, a medieval fortification and haven, is a town on the rocky peninsula. It used to be the headquarters of Pastrovici, and now it is exclusive tourist center (Fig. 1). It used to be an island, having traditional architecture of one-floor stone houses. This island's potentials were recognized after WWII. In 1955, the Government decided to valorize it for tourist purposes and create unique natural complex on Adriatic coast and on Balkans. At that point of time, this island had population of only 20 people. 80 preserved facilities were adopted. After the exclusive hotel was built, famous people from all around the globe significantly contributed to its successful promotion.

2. Old Town in Budva is another good representative of proper tourist valorization. Fortified town on this area existed even in ancient times (Fig.2). First mentioning of this Illyrian town was in V century BC, in Sophocles' documents. Later on, Budva was also known in Greek sources, when Aegean influence was in its prime. The most interesting sights of Old Town in Budva are: Citadel - which used to be a shelter (now, there are library and restaurant situated); and Antique necropolis - found in1938 on the location of modern hotel Avala. The oldest parts of necropolis originate from Illyrian-Greek period (III-II century BC). St John the Baptist's Catholic Church, the biggest and the tallest one in Budva, was built in VII century. Santa Maria in Punta, which used to be Benedict monastery, was built in IX century by monks on the cape ("in punta"). This church is not active regarding services, but it is used as a gallery space. Orthodox Church of Holy Trinity, was built in 1804 . It is rich with unique frescoes. Also, since 2003, there is Archeological Museum. 
City bastion, $1 \mathrm{~km}$ long, is a stage for various festivals during summer seasons, such as Folklore Festival, Mediterranean Song music festival and Theatre City. Within Old Town, there are numerous smaller hotels and apartments, as well as variety of commerce and restaurants. Without any doubt, city exploited is the essence of the tourist offer, which is the embryo of developing tourism.

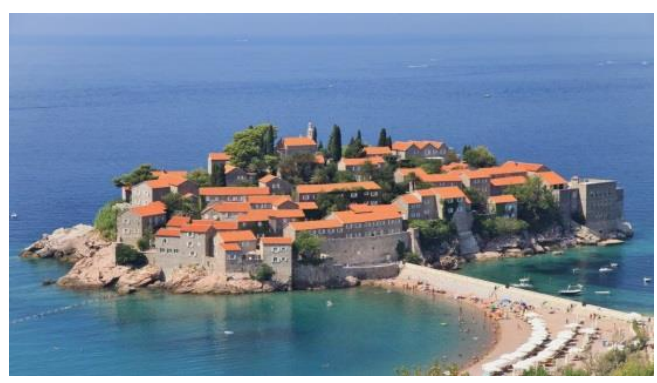

Fig. 1. Sveti Stefan.

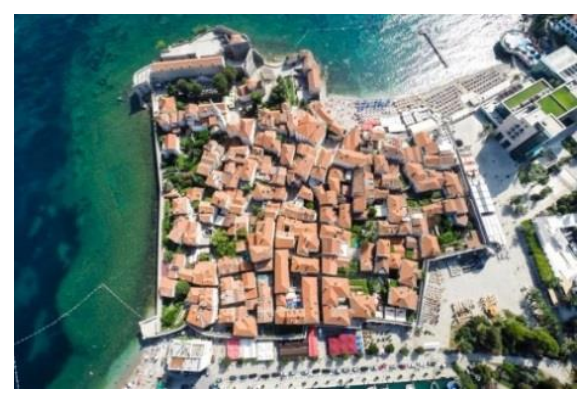

Fig. 2. Budva.

3. Kotor Old Town is situated on the most indrawn part of Boka Kotorska Bay (Fig. 3). Today, it is expanded outside the city walls and under UNESCO's protection. Boka Kotorska Bay is the deepest natural fjord in Mediterranean. It is the only East-Adriatic town, marked on every existing map so far. It can also be described as labyrinth-city. During tourist season, such urban structure is specially appreciated. Lately, Kotor is the most visited Montenegrin destination. Beside city walls, the most important sites are: Clock Tower (VIII century), St Tryphon's Catherdal (XII century), St Luka's Church (XII century), Prince's Palace (XVII century), St Mary's Cathedral (XII century), Church of Lady of the Health (XV century), Napoleon's Theatre (XIX century). Significant sum of family houses are influenced by previous epochs in their architecture. Kotor also has numerous palaces: Drago Palace with gothic windows from XV century, Byzanti Palace from XII century, Pima Palace with typical Renaissance and Baroque shapes from XVI century, Grubinje Palace with built-in coat of arms of ancient Kotor pharmacy established in 1326, Grgurina Palace from XVII century. Nowadays, that is a building of Maritime Museum [10] Significant disposable cultural heritage influenced other potentials, so significant number of hotels, restaurants, caffe bars and shops is situated within city walls. Kotor also became important destination of naval tourism regarding cruisers. The fact that Kotor was visited by cc500 cruisers and half million of tourists speaks volumes about it.

4. Perast is small, baroque town, having its prime in XVII and XVIII century (Fig.4). It belongs to Kotor municipality. Main activity of its inhabitants was sailing, and its sailors were recognized around the world (familiar at that point of time). Special peculiarity of this town is island of Lady of the Rocks. It was made artificially by piling up rocks. However, in 1630, the church was built, which has in its possession rich collection of coins with relieves of boats, which describe best development of naval activities in Boka. Perast is also a home of few wonderful baroque palaces, which used to belong to famous families: Viskovic Palace, originating from XVIII century; Zmajevic Palace, Renaissance style from XVII century; Smekja Palace, from XVIII century; Bujovic Palace, built in XVII century (today known as Museum of City of Perast); Balovic Palace, from XVIII century; St Nicholas Church, situated in the centre of the town (built in the beginning of XVII century); St Antun Church with monastery (built in XVII century) and St John the Baptist Church, originating from XVI century.

Perast is another example of good tourist valorization, having both historical monuments as well as hospitality facilities providing accommodation in its offer. 


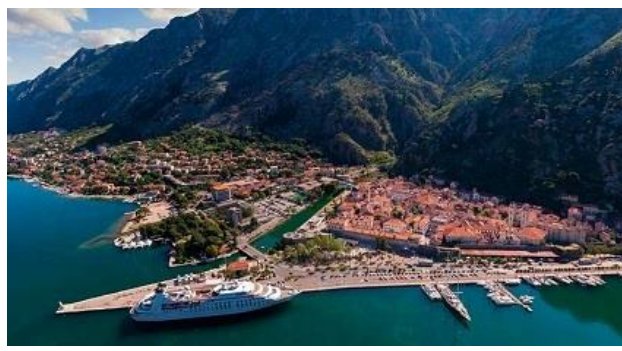

Fig. 3. Kotor.

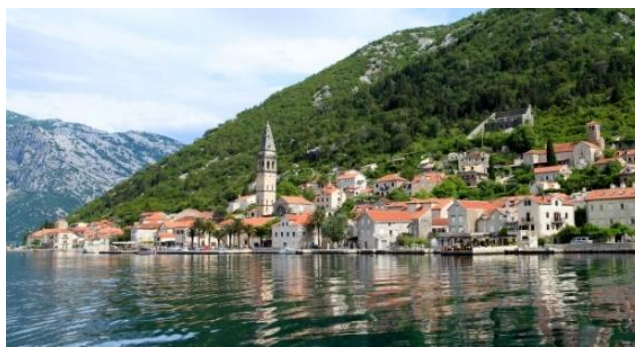

Fig. 4. Perast.

5. Historical core of Herceg-Novi, with its rich cultural heritage, always represented a significant potential for tourist valorization (Fig.5). It was continuously developed, but not always with same dynamics. On the very entry of Boka Kotorska Bay, king Tvrtko I established this town in 1382. The city was vanquished and devastated by Ottomans (1482, 1493, 1508), also held by Spanish (1538). In 1539, Turkish fleet general Hayreddin Barbarossa re-conquered it. Venetian Republic held it from 1687 until their ruin in 1797. Further on, Herceg-Novi has been ruled by Austrian-Hungarian Monarchy (1797-1806), Russians (up to 1807), French (up to 1814), Governemnt of Boka Kotorska and Montenegro for a short period of time, and finally Austrian-Hungarian Monarchy, up to 1918. During WWI and WWII, Herceg-Novi was usurped by Italians and Germans. Tourism began developing in XIX century. First records on that are by Simo Matavulj, about the "sjora Roza's inn" (sjora means dame). Tavern Bella Vista, owned by family of Savo Bacanovic was mentioned in 1872 with 25 beds "for foreigners". Contemporary hotel management in Herceg-Novi, started with building a boarding house "Pansion na Zelenoj Plazi" ("Boarding House on Green Beach") in Zelenika, later known only as hotel Plaza. The same can be applied for hotel management in all Boka Kotorska area. During the period between two world wars, two tourist associations were established Savina in Herceg-Novi in 1922 and Igalo in Igalo in 1924. Intensive and organized development of tourism of new age on this area is connected to 60ies of XX century, when most of the hotels were built (existing even nowadays), which are considered as modern and big ones for that period of time.

6. Ulcinj Old Town is an example of partially used existing capacity, even though potentials are not less than those of Herceg-Novi, Kotor, Perast or Budva Old Town (Fig.6). The earliest traces of Ulcinj go to prehistory, when this town used to belong to Illyrians. Its Old Town was established by Colchis, who named it Colichinium. In 163BC (II century), Illirian tribe Olcianitas fought with Romans and the town was conquered by great empire. The name of this ancient town is changed into Olcinium. However, during Roman rule, this city had a special status and privileges (oppidum civium Romanorum), and later on it was proclaimed to be a city with independent status (municipium). Due to its extraordinary geographic position, relief and mild climate, it was always a target of grand conquerors. Byzantine tsar Justinian renewed this city and built fortifications, and afterwards, Nemanjics, Balsics, Venetian Republic and Ottomans did the same. In 1883, Serbian mayor Stefan Nemanja conquered it. For the time of Ottoman Empire rule (15711880), Ulcinj and its commercial fleet were pillars of Ottoman Empire on Adriatic.

Ulcinj acquired freedom in January 11, 1878, whereas it was united with Principality of Montenegro in November 30, 1880 [13] Development of Old Town of Ulcinj has taken a swing only recently, which is not easy to explain because of its capacities. Only a few hotels and restaurants are listed in its tourist offer, whereas other objects are not actively promoted enough. 


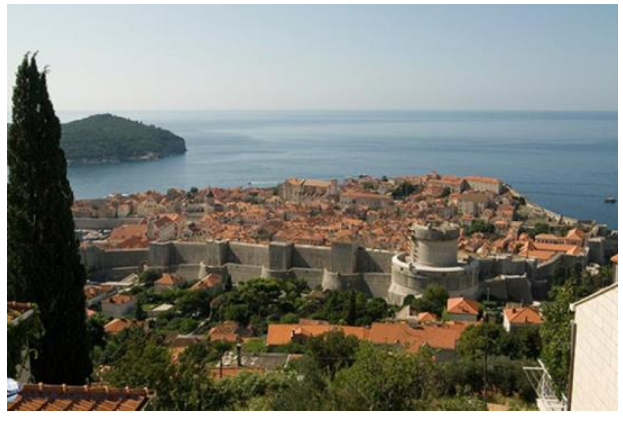

Fig. 5. Herceg-Novi.

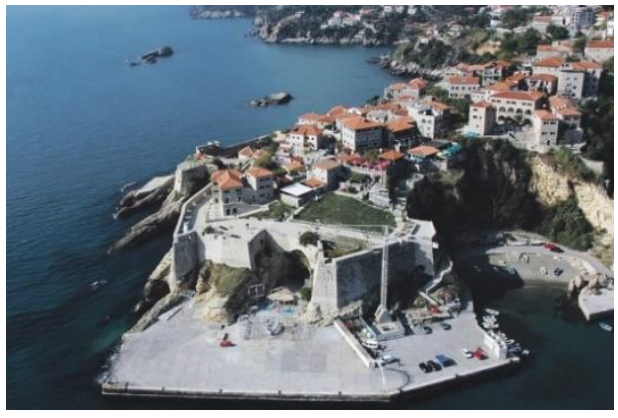

Fig. 6. Ulcinj.

7. Cetinje is a good example of proper tourist valorization. Its urban structure is of both historic and architectural value, with the crucial facilities mostly connected to creating state of Montenegro. What can be said for Cetinje is that it is the example of careful and thorough management stimulated by the state.

On the exact spot where the court of Ivan Crnojevic was located, vladika Danilo (bishop) founded Monastery of Cetinje in 1701. His residence, Biljarda (Billiards' house), built in 1838 , was in vicinity of this facility. Independence of Montenegro was proclaimed at Congress of Berlin in 1878, when Cetinje became royal capital. During the rule of Nikola I, new court, hospital, the first hotel and Institute for Women were established.

Because of the acquired position, Embassies had to be built in Cetinje (Fig.7,8). These facilities were used in different architectural styles, which significantly influenced valorization of Cetinje for tourist purposes. There are three great Christian relics situated in Cetinje: hand of St John the Baptist, piece of Honorable Lord's Cross and the icon of Virgin Filermosa. The first two are preserved in Monastery of Cetinje, while the third one is preserved in Blue Chapel of Assembly House. Monastery of Cetinje was built in 1702 by vladika Danilo Petrovic. It is located in vicinity of Biljarda and King Nikola's Court.

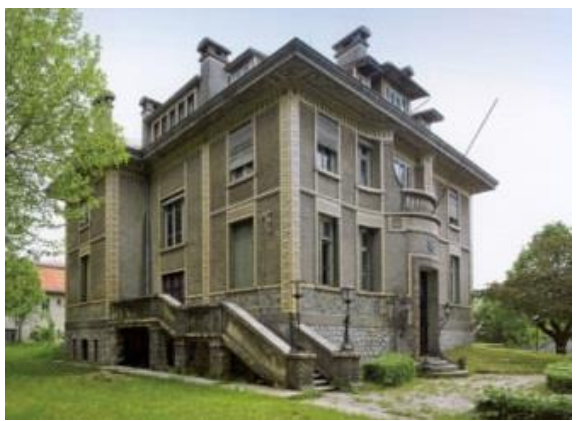

Fig. 7. French Legation.

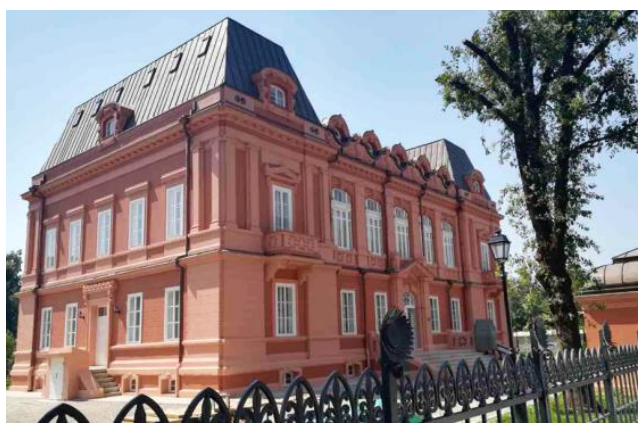

Fig. 8. Russian Legation.

Cetinje has tourist offer for religious tourism in following: Crnojevic Monastery with Holy Mother's Church (founded by Ivan Crnojevic in 1484, who was also a founder of Cetinje) and Vlach Church (founded in XV century). Monastery was devastated by Ottomans in 1692. King Nikola I built a chapel on the location of Holy Mother's Church in 1886. Today, this chapel contains remains of king Nikola I and queen Milena. Vlach Church was devastated in XVII and XVIII century.

Cetinje is also the city of museums. There are: Monastery of Cetinje's Museum, Historical Museum, National Museum of Montenegro (located in former building of Serbian Legation), Museum of Njegos (dedicated to Petar II Petrovic Njegos, set in Biljarda), birth house of 
Njegos (located in Njegusi, in hamlet Erakovici), King Nikola's Museum (in king Nikola's court), Art Museum of Montenegro (in building of Parliament) [14]

\section{Unused or insufficiently used capacities}

Regarding unused chances, insufficient engagement of management in certain areas is present in spite of significant potential for tourism development. That is especially obvious with smaller urban units and separate facilities, which could be of great significance for tourism development and important synergy element with other tourist capacities and general tourist offer.

Unfortunately, this work cannot deal with all Montenegrin disposable capacities, but noticing considerable number of them points to management omissions that cannot be taken for granted. Special problem is temporal factor which influences ruining and devastation while reconstruction and restoration demands considerable financial means.

\subsection{Old Town Bar}

Bar is a town on the Adriatic coast, which became part of Montenegro in 1878. Ottoman Empire conquered it from Venetian Republic in 1571, as a fortified city named Antivari (Fig.9). It had certain privileges given by Ottoman Porte, which is confirmed in charter signed by sultan Murat III, in June 1575 .

Ottomans found clock tower next to the church in this Venetian city. It had been damaged by military operation and was kept in that condition until 1753. It was restored by haji-Jahjaagha Ibrahim, who bequeathed part of his property in vaquf for its maintenance. When Montenegrins re-conquered it, normal living was impossible to be organized within this fortress. Population moved to suburbs initially. Clock Tower was considerably demolished back then and it was restored to its current form in 1922.

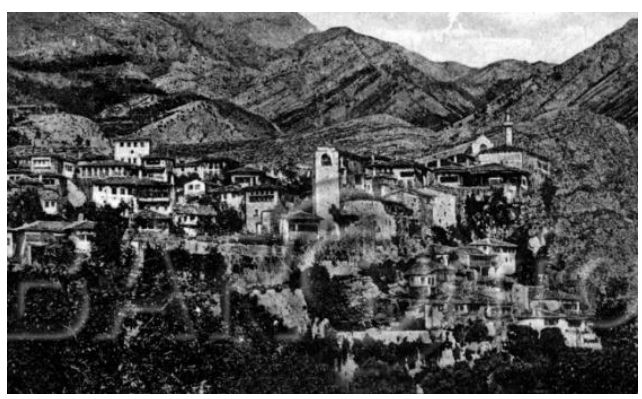

Fig. 9. Old Bar in 1877.

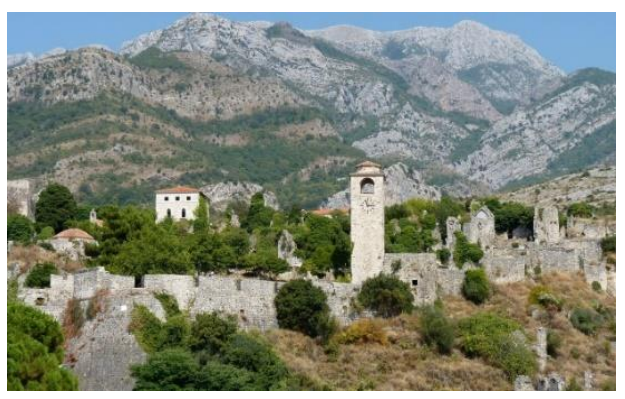

Fig. 10. Old Bar today.

Old Bar is partially activated with sacral facilities, museum, Clock Tower and open stage (Fig.10). Hamam (public bathroom) is not restored and the same can be applied to many other facilities which can be considerable addition to tourist offer. This is the only Old Town on Montenegrin Adriatic coast which does not offer accommodation nor hospitality facilities within its city walls, which is not common.

\subsection{Gornja Brca}

This borough belongs to municipality of Bar. Architectural rarities are facilities set parallel by contour lines. Main feature of this architecture are towers with vaults, imbued with stone, wood and iron (Fig.11,12). This borough is only few hundred meters away from Sutomore 
beach. This location was so appealing that even Venetian countesses came here for summer vacation. Nowadays, splendid palaces in Gornja Brca are abandoned and forgotten. It is hard to believe that no one was interested for their valorization despite of vicinity of Sutomore, famous summer resort.

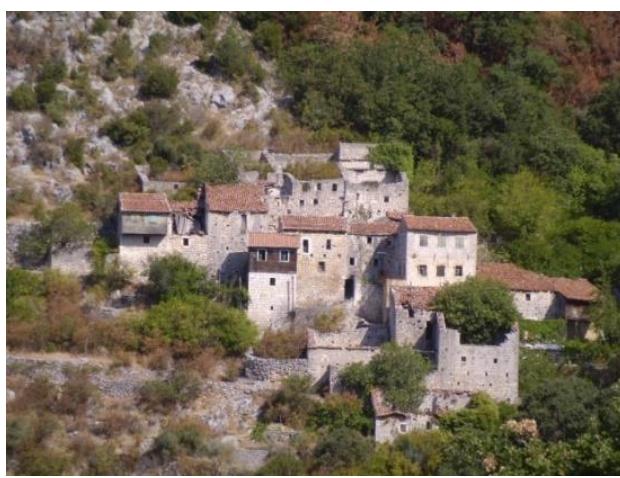

Fig. 11. Gornja Brca.

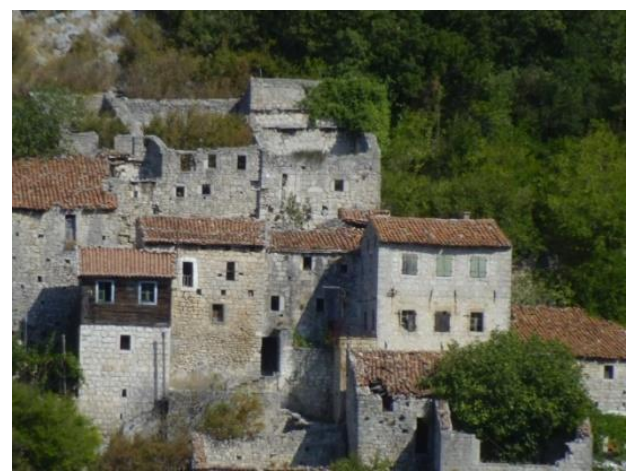

Fig. 12. Gornja Brca.

Homogenous urban structure is a perfect example of "group form" in architecture, and their special feature is considerable applying of wooden elements, which is not so frequent in Mediterranean architecture.

\subsection{Godinje}

Godinje, in municipality of Bar, is authentic and compact urban agglomeration on the northern slope of Rumija. This settlement is oriented towards Skadar Lake and it is extraordinary valuable, which is one of the largest zones of this lake. It is the example of high-quality vernacular architecture, with values are both architectural and urban qualities (Fig.13,14,15). This kind of agglomeration is the thick one, following terrain configuration and logically positioned on terrain, carefully respecting view of each house existing. Special jewel of this town are basement floors with wineries, as well as gardens formed by houses disposition - they were created as a consequence of families' stratification. Basement floors were mutually connected by underground tunnels, which was crucial for defense of this town.

Its valorization for tourist purposes is possible because this is almost abandoned settlement, having preserved its main values, both architectural and urban.

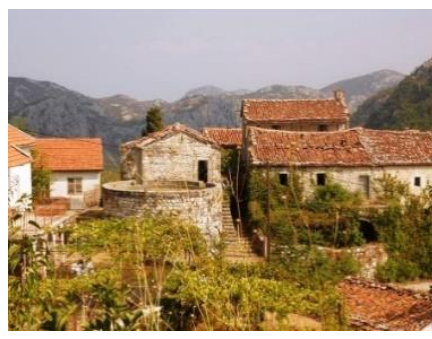

Fig. 13. Godinje. Appearance. Urban disposition and fragment.

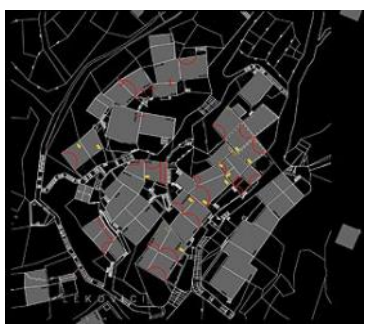

Fig. 14. Godinje. Appearance. Urban disposition and fragment.

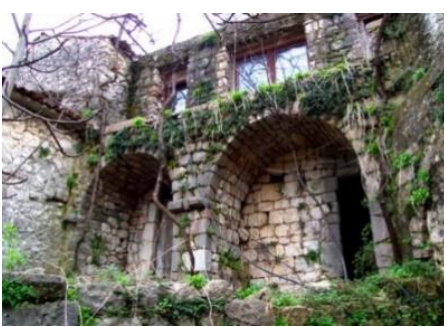

Fig. 15. Godinje. Appearance. Urban disposition and fragment.

\subsection{Poseljani}


Poseljani, in municipality of Cetinje, is a village on Skadar Lake (Fig.16,17). This is situated on the middle of the road Virpazar-Rijeka Crnojevica. Village is set in the vicinity of Skadar Lake. Above the village, there is a monument dedicated to soldiers of WWII. This used to be very important village, because there were 15 mills for grinding wheat. Both land and lake approaches to the village were active. As time passed by, requirement for mills decreased, so the village almost went silent. Only stone walls with ivies overgrown remained. Most of the houses appear to be that way. Altogether, this village can be perceived as quality tourist offer.

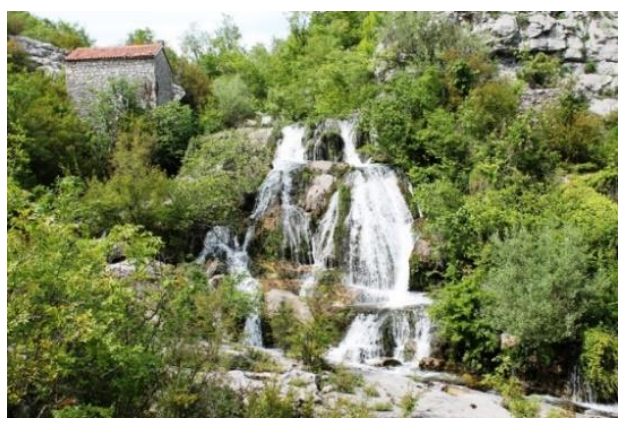

Fig. 16. Poseljani. House, waterfalls and stone bridge.

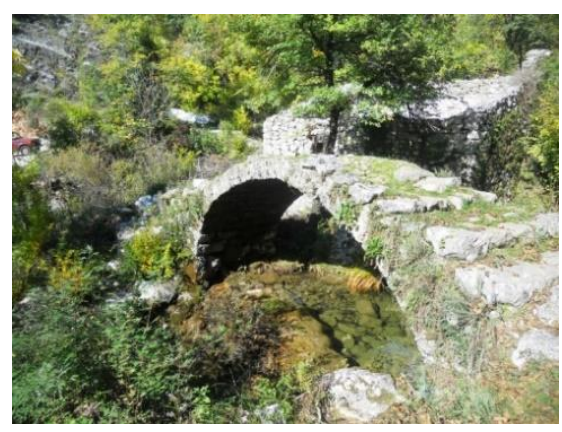

Fig. 17. Poseljani. House, waterfalls and stone bridge.

\subsection{Dodosi and Karuc}

Dodosi and Karuc are fishermen and agricultural settlements on Skadar Lake, belonging to municipality of Cetinje (Fig.18,19). Considering the fact that building material was stone mostly, they are still remarkably preserved and partially populated, which is considered to be an important factor. Their tourist valorization is left over to individual initiative, without support of wider social associations, because this potential was not recognized.

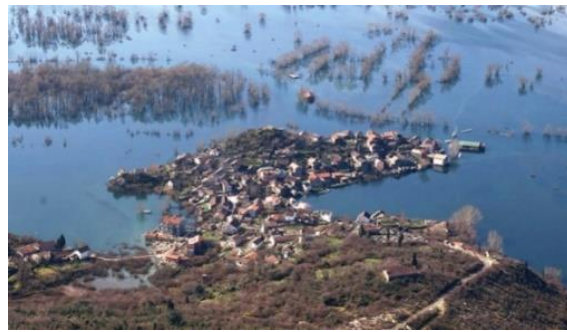

Fig. 18. Dodosi.

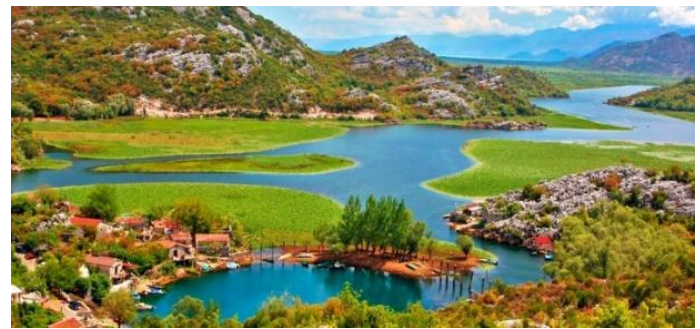

Fig. 19. Fishermen settlement Karuc.

\subsection{Boka Kotorska forts}

Fortifications from Austro-Hungarian period can be significant tourist potential, unfortunately, not properly used in Montenegro. These facilities are preserved well, made out of stone with highly sophisticated skill and knowledge of engineers for the time of their origin. They current state is remarkable, so lately valorization of few of them has started. More precisely, fortress on island Mamula, on the entrance to Boka Kotorska Bay has started recently (Fig. 20, 21). 


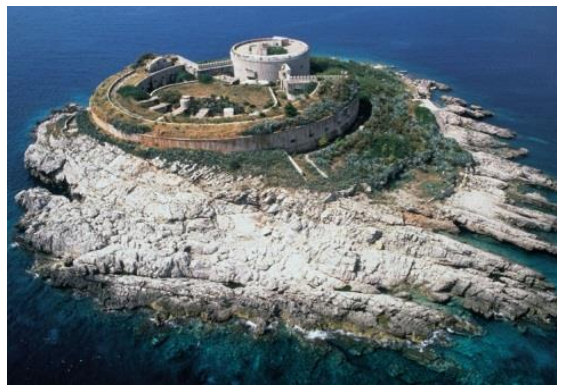

Fig. 20. Mamula island with fortress Current condition.

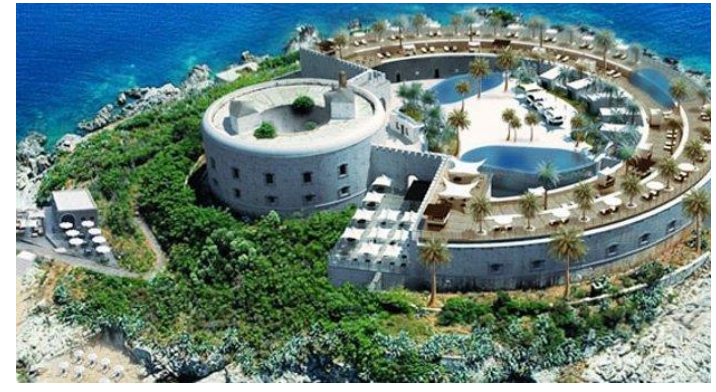

Fig. 21. Mamula island with valorized fortress Design of valorization into luxury hotel.

Such kind of facility can be valorized for various purposes: accommodation, restaurants, night clubs, which requires certain studies done previously. However, what is evident is the fact that, only very few of them allow organized tourist visits or are of museum character.

\subsection{Old Town Podgorica}

As a settlement, Podgorica is mentioned for the first time in 1326, in one court document of Kotor's Archive. The most famous and important part of what we today know as Podgorica, is Roman town Doclea. Podgorica underwent Ottoman rule in 1474, when Mehmed II the Conquerer was leading this empire [16]

That event was the beginning of 4 centuries long Ottoman rule on this area and further. On the place where Ribnica confluences into Moraca, Ottomans built fortification named Depedogen, where the settlement, today known as Old Town, was established (Fig. 22).

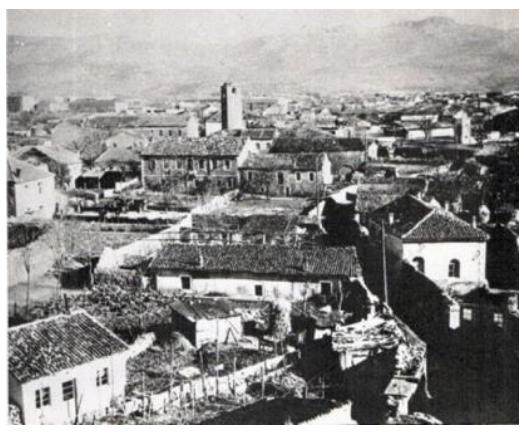

Fig. 22. Podgorica Old Town in 1879.

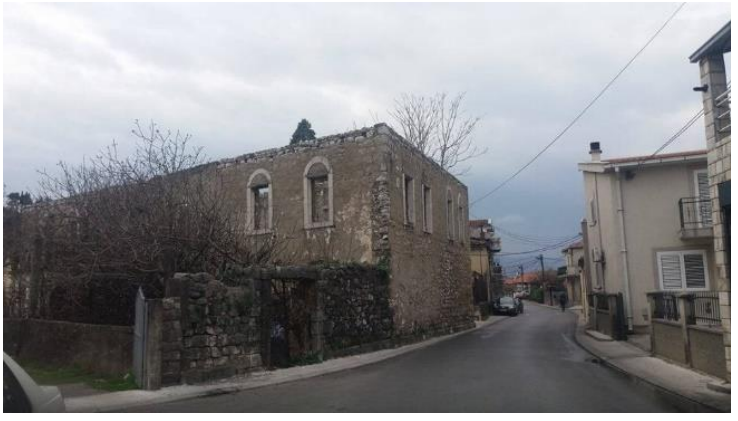

Fig. 23. Ruined facilities in Old Town today.

Urban agglomeration of oriental type is not valorized so far, even though there are favorable conditions for such valorization (Fig. 23). Authentic residential facilities, which have inner gardens, are potentially apartment settlement, hospitality facilities as well as different crafts. Such approach would significantly contribute to Podgorica's tourist offer and have significant economical effects.

\subsection{Rozaje, Plav and Gusinje - defensive residential towers}

Forementioned facilities on the north of Montenegro are remarkably appealing and unique in architectural sense, having both residential and defensive functions. Their main feature is a combination of stone pedestal spreading out on two grounds and a wooden floor as the final one. They are covered with pyramid wooden roof with tiles. In Rozaje, there is one such facility, mostly ruined, named Ganic tower (Fig. 24). Another one, situated in Plav, is 
protected as immobile cultural heritage and it kind of museum nowadays - Redzepagic tower (Fig.25). There is also another kind of such towers completely made out of stone, located in Plav and Gusinje. Their functional scheme is completely the same as the scheme of these towers. At least 21 of such towers can be valorized in Plav and Gusinje, of course, none of them is currently part of valorized tourist offer.

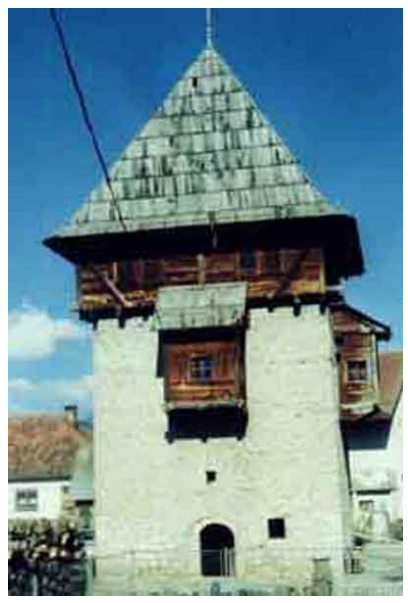

Fig. 24. Redzepagic Tower, Plav.

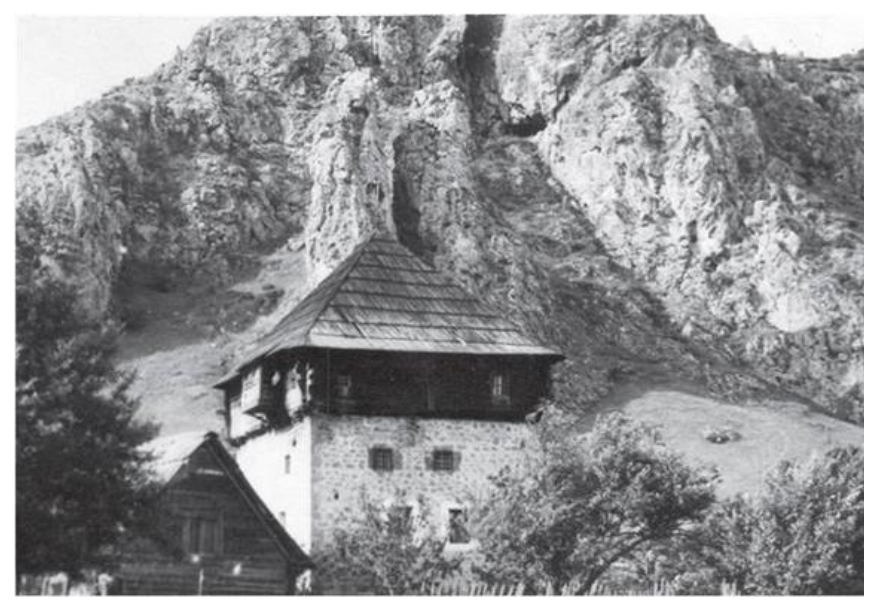

Fig. 25. Ganic Tower, Rozaje.

Beside obvious museum feature, these towers can be also addressed as exclusive utilitarian function of original function, also applicable for purposes of tourist offer.

\subsection{Houses built in oriental style on the north of Montenegro}

Bijelo Polje, Pljevlja (Fig. 26), Rozaje (Fig. 27), Plav and Gusinje are still in possession of preserved residential facilities originating from Ottoman period. Such facilities can be valorized for the tourist purposes, more importantly because they represent a specific architectural residential shape which is symbiosis of oriental type of building and architectural features of indigenous tradition.

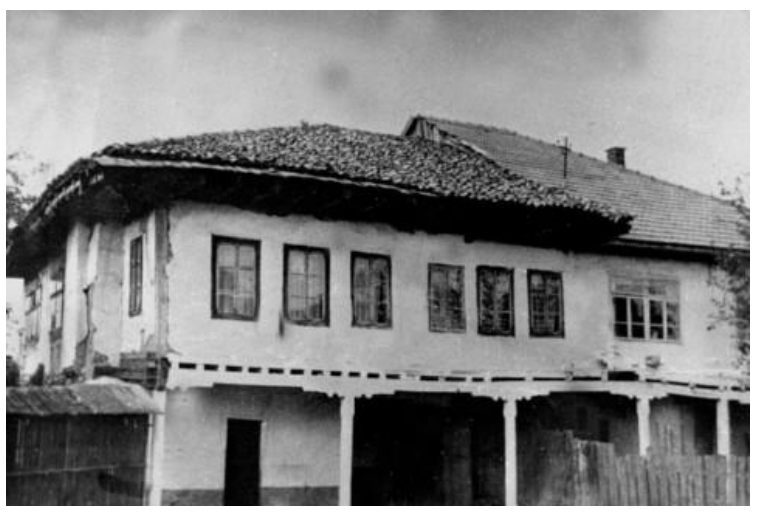

Fig. 26. Oriental type of house, Pljevlja.

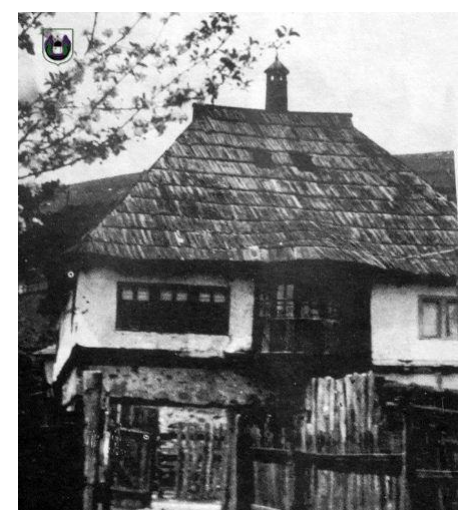

Fig. 27. Oriental type of house, Rozaje.

Even though they are evidently ruined, these facilities can also be used for purposes of renting to visitors, not only of museum characteristics. Original interior is still preserved on 
some of them, but they can also be restored into their original condition. Doubtlessly, urban core of any of these towns would get some historic depth and richness in distinctiveness this way. Of course, all these elements contribute to final economical effects and synergies of tourist offer.

\subsection{Dinaric type of house}

Dinaric type of house is defined and recognized type of house, existing for 600 years at least. It was wide spread on the area of Dinaric mountains, so that is the origin of their name. It was significantly present at the north of Montenegro, but only rare facilities are remaining.

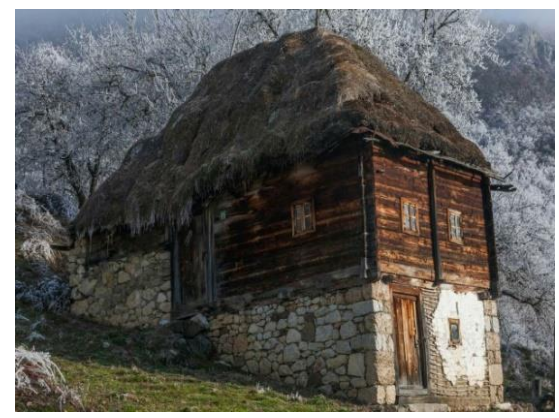

Fig. 28. Dinaric type of house in vicinity of Bijelo Polje.

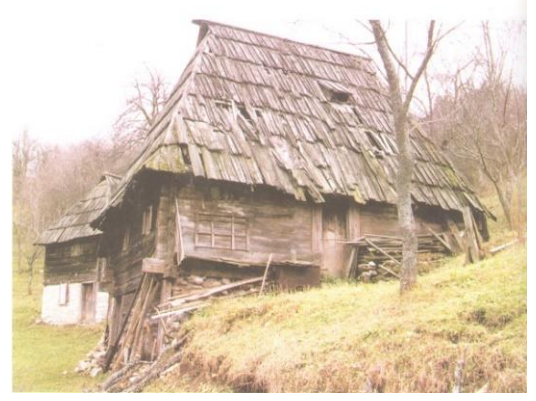

Fig. 29. Dinaric type of house in vicinity of Bijelo Polje.

The main feature of such houses is their building at the steep terrain, where the half of the house serves as izba - space for lodging of cattle, while the other half is on the ground. In other words, this type of house consists of two parts - one of them, under the ground, is izba, while the other one is above the ground. Above izba, there were one or more rooms. Above the upper floor, there was no attic, but the space used for open fireplace.

This type of house is still preserved in Bijelo Polje, Berane and Pljevlja, for example (Fig. $28,29)$. None of them are protected as cultural heritage. On the other side, if they were actively promoted as rarities, it could be only beneficial for village tourism.

\subsection{Katuns of Montenegro}

Katuns in Montenegro are special feature, having long tradition and present in all Montenegrin territory, from North to South. They were response to occasional and temporary migration of cattle during summer season (Fig. 30, 31, 32). On both South and North, this migration was from lower altitude to higher ones, where vegetation was lush and temperature was lower.

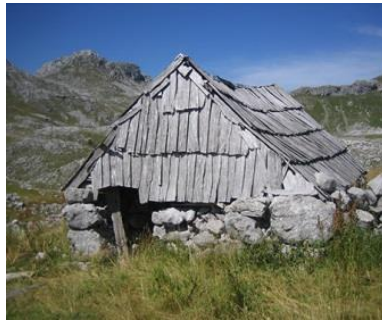

Fig. 30. Katun on Komovi.

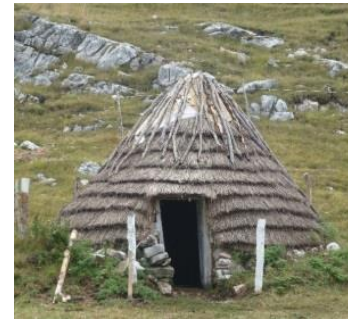

Fig. 31. Savardak on Bjelasica.

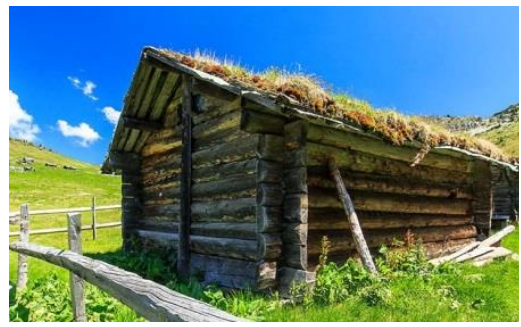

Fig. 32. Katun on mountain Stedim. 
Only situation where the case was vice versa was vicinity of Skadar Lake. During the summer, due to drought, people migrated from the higher altitudes to the lower ones, near the water, where plants were spread wider.

This process crystallized numerous types of katuns being of square, rectangular and circular forms. They were covered mostly with wood, but the turf was also used for this purpose (example: savardak, circular type).

Chance for affirmation of such facilities for tourist purposes definitely exists. There are also examples where such potentials are already used for tourist purposes.

\section{Conclusion}

By analyses of total condition of valorization of disposable potentials of urban units and individual architectural facilities, real cross section of this issue is been made. It is clearly stated that adequate and skilled management lacks, which would further influence expected process. It is obvious that certain potentials are recognized, or may be imposed, at the seaside (South part), rather than on North or Central part of Montenegro. Valorization process of disposable qualities, which were promoted as successful ones, was mostly performed in period of Socialistic Yugoslavia, when planned economy was respected. This fact speaks volumes about larger presence of sophisticated management during that time rather than transition period from 1990 onwards. However, it also states about putting emphasis on sea tourism, which was already making some tourist infrastructure. So, the certain segments mentioned here, were constantly imposing because of their qualities, leading further on to their valorization. Example of unused potentials of Old Bar or insufficient formation of Ulcinj Old Town again confirms non-equivalent course of process and dynamics of development not being even.

What is considered to be acute issue is that central part is neglected and quality agglomeration in vicinity of Skadar Lake. These areas are not sufficiently included in tourist offer because of improper management not promoting their qualities. The same applies to inhibition of promotion of Old Town in Podgorica, another example of inadequate management.

However, the best example for unconvincing management is definitely management of North of Montenegro. This is the location where were located (and still are located) significant potentials of architectural facilities in both rural and urban environments. Active promotion of these potentials, along with other advantages that this region can offer to tourists, is one of the last strongholds which could prevent further migration of people from that area.

Beside inadequate management, economic policy is to be reconsidered also, which does not affirm North region, further influencing demography of this region, which deteriorates.

To sum up the conclusion, the fact is that Montenegro does not possess properly educated and professionally convincing management which would impose their opinions to ruling parties, for longer period of time. If so, it could lead to active promotion of all tourist capacities.

\section{References}

1. Z. Shen, Support of Urban Planning and Management (Springer International Publishing, Switzerland, 2018)

2. A.M. Colavitti, Urban Heritage Management (Springer International Publishing, Switzerland, 2018) 
3. V. Crne, Gore Ministarstvo kulture. Menadžment Plan prirodnog i kulkturno-istorijskog područja Kotora (Nacrt, Cetinje, 2011)

4. V. Crne, Gore Ministarstvo kultureMenadžment plan istorijskog jezgra Cetinja (Cetinje, 2014)

5. M. Bulatović, Crna Gora - Ekoloska drzava (Unireks, Podgorica, 1996)

6. Expediitio, Skadarsko jezero - studija potencijala za održivi prostorni razvoj (Kotor, 2009)

7. R. Pavićević, Austrougarske tvrđave u Crnoj Gori Pobjeda (Herceg Novi, Podgorica, 2012)

8. H. Markišić, Kullturno-istorijsko nasljeđe Plavsko-Gusinjskog kraja (Almanah, Podgorica, 2017)

9. R. Findrik, Dinarska brvnara (Muzej «Staro selo», Sirogojno, 1998)

10. K. Mitrović, Knjiga o Kotoru (Magelan press, Magelan, 2013)

11. Expeditio, Vodič kroz Perast (Expaditio, Kotor, 2009)

12. B. Ilijanić, Herceg Novi Grad i graditeljsko nasljeđe (Ilibo Design Arcjhitect, Herceg Novi, 2015)

13. M. P-Kovačević, Gradovi i utvrđenja u Crnoj Gori (Beograd, Ulcinj, 1975)

14. G. Radović, Arhitektura Cetinja od XV vijeka do II svjetskog rata (CANU, Podgorica, 2012)

15. Z. Ivanović, Urbani razvoj gradova Crne Gore u Turskoj imperiji (Geografski institut Filozofskog fakulteta u Nikšiću, Nikšić, 2013)

16. D. Ičević, Glavni grad Podgorica (Glavni grad Podgorica, 2013) 